() О. О. Палюх, к.т.н., доцент, КПІ ім. Ігоря Сікорського, Київ, Україна

\title{
ДОСЛІДЖЕННЯ КЛЕЮЧОЇ ЗДАТНОСТІ ОКРЕМИХ ВИДІВ КЛЕЇВ ДЛЯ ВИГОТОВЛЕННЯ КНИЖКОВИХ ОПРАВ ІЗ ПАЛІТУРНИХ МАТЕРІАЛІВ З РІЗНИМИ ТЕХНОЛОГІЧНИМИ ВЛАСТИВОСТЯМИ
}

На прикладі проведених досліджень виготовлення книжкових оправ, виявлено необхідні для практичного використання залежності, що виникають при використанні окремих видів клеїв із різними технологічними властивостями та різних палітурних матеріалів, що комплексно забезпечують виготовлення спрощених обкладинок за попередньо заданими основними характеристиками, дотримання яких забезпечить високоякісний та конкурентоздатний вид книжкової оправи.

Ключові слова: книжкові оправи; палітурка; обкладинка; клеюча здатність; зусилля роз'єднання; розшарування зразків.

\section{Постановка проблеми}

Завданням для дослідження клеючої здатності окремих видів клеїв, що застосовуються для виготовлення книжкових оправ із палітурних матеріалів з різними технологічними властивостями $\epsilon$ визначення максимальних зусиль, за яких відбувається розшарування зразків, склеєних між собою. На підставі отриманих результатів випрацювати рекомендації пріоритетності застосування окремих палітурних матеріалів і клеїв при виготовленні різноманітних інтегральних та спрощених обкладинок з метою мінімізації витрат на їх виготовлення за умови використання ресурсозберігаючих технологічних процесів.

\section{Аналіз попередніх} досліджень

Широко відомим $є$ виготовлення книг у традиційних жорстких та м'яких оправах [1-3], що потребує залучення значної кількості поліграфічних процесів, використання дорогих матеріалів [4, 5], енергетичних та людських ресурсів. Вони здатні служити довгі роки і при дбайливому поводженні зберігають свій презентабельний вигляд.

Міцність і якість, що виділяють подібні книги сприяють застосуванню технології їх виготовлення для підручників, довідкової літератури та видань, що активно читаються не один раз впродовж довготривалих періодів. Але собівартість книг в палітурці в кілька

(c) $2017 \mathrm{p}$. 
разів вище аналогів у обкладинці, що виділяються низькою собівартістю і конкурентною ціною [6]. 3 іншого боку, за активної експлуатації обкладинка вже через декілька тижнів «активного» читання втрачає свою привабливість. Після чого починається процес поступового руйнування книги.

Через щільне конкурентне середовище на ринку поліграфічних послуг [7] набуло розповсюдження виготовлення та використання в книжкових оправах інтегральних та інших спрощених обкладинок [8]. У процесі виготовлення таких обкладинок [9] використовуються різноманітні поліграфічні матеріали: баладек, бумвініл, задрукований тонкий картон 3 ламінованою поверхнею, щільний папір тощо, що мають зовнішню та внутрішню площину, різні за шорсткістю, гладкістю, зчіплюваністю. Попередньо вирубаний із матеріалу контур заготовки для виготовлення обкладинки має мінімальні припуски для загинання й приклеювання крайок [10], що потребує оцінювання сумісності використання матеріалів та клеїв для забезпечення міцності склеювання та дотримання каліброваних розмірів контуру обкладинки й її мінімальної товщини у місці склеювання.

Вивченню особливостей поліграфічних матеріалів, умов їх використання у технологічних процесах 3 виготовлення книг, брошур та іншої поліграфічної продукції, дослідженню клеїв, що застосовуються при незшивному скріпленні, при виготовленні твердих оправ книг та іншим особливостям використання сполучення палітурний матеріал + клей присвячені роботи українських вчених Лазаренка Е. Т., Гавенко С. Ф., Валуєнка Б. В., Мартинюка М. С. тощо. Результати досліджень частково використані в державних стандартах «Видання. Видавниче оформлення і поліграфічне виконання. Номенклатура показників якості» та «Поліграфія. Обкладинки та палітурки. Типи».

\section{Мета роботи}

Аналіз клеючої здатності окремих видів клеїв для виготовлення книжкових оправ із палітурних матеріалів 3 різними технологічними властивостями 3 метою отримання результатів щодо пріоритетності застосування матеріалів і клеїв при виготовленні інтегральних та спрощених оправ для книг, що сприяє мінімізації витратної частини виготовлення книг за умови збереження основних переваг палітурки.

\section{Результати проведених досліджень}

Для визначення клеючої здатності клеїв, що застосовуються для виготовлення книжкових оправ із палітурних матеріалів з різними технологічними властивостями необхідно визначити максимальні зусилля, за яких відбувається розшарування стандартних зразків, склеєних між собою клеєм, який випробовується.

Для проведення досліджень були використані такі клеї: PLAKAL Batch 6602 (Німеччина), термоклей Tecnomelt 3660 (Hiмеччина), термоклей Swift therm 8026 (Фінляндія), дисперсія полівініл-ацетатна ПВАД 51-П 
(Україна), дисперсія полівінілацетатна ПВАД ДФ-51/15В (Україна). Для склеювання та визначення зусиль, що призводять до розшарування, застосовувалися наступні матеріали: офсетний папір 100 г/м² з ламінацією, папір для форзаців 120, 150 та 170 г/м², палітурний матеріал 3 нітроцелюлозним покриттям (баладек), хромерзац, картон товщиною 1,50, 1,75, 2,00, 2,25 та 4,00 мм, виробників Алексінський ПКК, Луцький ПКК, Голандія.

Експериментальні дослідження виконувалися на розривній машині РМБ-30 з граничним навантаженням не менше $50 \mathrm{H}$ (5 кГс), ціною поділки шкали A не більше 0,02 кГс і вантажем, що здійснює тиск на склейку близько 0,001 МПа (0,01 кГс/см²).

Зразки, призначені для випробовування, представляють дві смужки палітурних матеріалів, що досліджуються, довжиною по 100 мм і шириною по 15 мм, склеєних між собою зі зворотного боку клеями, які випробовуються.

Клей PLAKAL Batch 6602 (Hiмеччина): в'язкість - 1600 200 (мПа); температура застигання 36,0 C; показник рефракції - $45 \%$.

Термоклей Tecnomelt 3660 (Німеччина): робоча температура - 160-180 C; час відкритої витримки - 25-30 с.

Термоклей Swift therm 8531 (Фінляндія): робоча температура - 150-180 С; час відкритої витримки - 20-30 с.

ПВАД (Полівінілацетатна дисперсія) марка 51-П: в'язкість 80-100 с; клеюча здатність 0,78 кГс/см; час схоплювання $13 \mathrm{c}$.
ПВАД (Полівінілацетатна дисперсія) марка ДФ 51/15В: в'язкість - 60-80 с; клеюча здатність - 0,66 кГс/см; час схоплювання -20 с.

Для склеювання смужок на зворотній бік однієї з них на відстані 20 мм від краю пензликом наносився тонкий рівномірний шар клею (площа склейки 20×15 мм), потім на неї накладалася зворотним боком друга смужка, ретельно притискаючи краї по усій довжині смужок.

Склеєні смужки були поміщені під вантаж, питомий тиск якого на склейку здійснювався зусиллям у 0,01 кГс/см². Склейки витримувались за кімнатної температури протягом однієї год під тиском, а потім 24 год без тиску.

Одночасно у такий спосіб були підготовлені п'ять таких зразків кожного виду матеріалів, призначених для досліджень, для паралельного визначення клеючої здатності клеїв.

у затискач розривної машини закріплювались вільні краї смужок. Випробовування проводились за швидкості руху нижнього затискача 55 мм/хв. Фіксувались найбільші зусилля, за яких відбувалося повне роз'єднання склеєних смужок різних палітурних матеріалів.

Клеюча здатність (Q) в кГс/см розраховувалась за формулою:

$$
Q=\frac{P}{B}=\frac{P}{1,5}
$$

де $\mathrm{P}$ - середнє арифметичне із п'яти значень максимального зусилля, при якому роз'єднуються зразки, кГс; в - ширина смужок, які склеюють, см (в = 1,5). 
Отримані результати максимальних зусиль роз'єднання склеєних зразків палітурних матеріа-

лів, що досліджувалися, та розрахована клеюча здатність клеїв наведені у табл. і рис. 1-9.

Результати максимальних зусиль роз'єднання склеєних зразків палітурних матеріалів та розрахована клеюча здатність клеїв

\begin{tabular}{|c|c|c|c|c|c|c|c|c|c|c|c|}
\hline \multirow{3}{*}{$\begin{array}{l}\text { № } \\
\Pi / \Pi\end{array}$} & \multirow{3}{*}{$\begin{array}{l}\text { Назва } \\
\text { клею, } \\
\text { вироб- } \\
\text { ник }\end{array}$} & \multicolumn{2}{|c|}{ Назва матеріалу } & \multicolumn{4}{|c|}{$\begin{array}{c}\text { Максимальне зусилля } \\
\text { роз'єднання склеєних } \\
\text { зразків, кГс }\end{array}$} & \multirow{2}{*}{\multicolumn{2}{|c|}{$\begin{array}{c}\text { Середнє } \\
\text { значення } \\
\text { всіх зраз- } \\
\text { ків, кГс }\end{array}$}} & \multirow{3}{*}{$\begin{array}{l}\text { Кле- } \\
\text { юча } \\
\text { здат- } \\
\text { ність, } \\
\text { кГс/см }\end{array}$} & \multirow{3}{*}{ Примітка } \\
\hline & & \multirow{2}{*}{$\begin{array}{c}\text { Крию- } \\
\text { чий ма- } \\
\text { теріал } \\
\text { палітур- } \\
\text { ки }\end{array}$} & \multirow{2}{*}{$\begin{array}{c}\text { Картон } \\
\text { палітур- } \\
\text { ний, ви- } \\
\text { робник, } \\
\text { товщина, } \\
\text { мм }\end{array}$} & \multicolumn{4}{|c|}{ Номер зразка } & & & & \\
\hline & & & & 1 & 2 & 3 & 4 & 5 & & & \\
\hline $\begin{array}{l}\text { I. } \\
1 .\end{array}$ & & & $\begin{array}{l}\text { товщ. } 1,50 \\
\text { Луцький } 1\end{array}$ & 0,56 & 0,53 & 0,54 & 0,56 & 0,55 & 0,548 & 0,365 & \\
\hline 2. & & & $\begin{array}{c}\text { товщ. 1,75 } \\
\text { Луцький }\end{array}$ & 0,55 & 0,54 & 0,55 & 0,54 & 0,55 & 0,546 & 0,364 & \\
\hline 3. & & & $\begin{array}{c}\text { товщ. 2,00 } \\
\text { Луцький }\end{array}$ & 0,56 & 0,55 & 0,54 & 0,54 & 0,56 & 0,550 & 0,367 & \\
\hline 4. & & $\begin{array}{c}\text { Папір } \\
\text { ламіно- }\end{array}$ & $\begin{array}{c}\text { товщ. } 1,50 \\
\text { Алек- } \\
\text { сінський }\end{array}$ & 0,57 & 0,57 & 0,57 & 0,56 & 0,55 & 0,564 & 0,376 & \\
\hline 5. & & $\begin{array}{c}\text { ваний } \\
\text { плівкою }\end{array}$ & $\begin{array}{c}\text { товщ. 1,75 } \\
\text { Алек- } \\
\text { сінський }\end{array}$ & 0,56 & 0,57 & 0,58 & 0,57 & 0,56 & 0,568 & 0,379 & \\
\hline 6. & & & $\begin{array}{c}\text { товщ. 2,25 } \\
\text { Алек- } \\
\text { сінський } \\
\end{array}$ & 0,56 & 0,56 & 0,57 & 0,56 & 0,57 & 0,564 & 0,376 & \\
\hline 7. & & & \begin{tabular}{|l|} 
товщ. 2,00 \\
Голандія 3 \\
\end{tabular} & 0,59 & 0,60 & 0,60 & 0,59 & 0,59 & 0,594 & 0,396 & $\begin{array}{c}\text { Розривна } \\
\text { машина }\end{array}$ \\
\hline 8. & $\begin{array}{c}\text { PLAKAL } \\
\text { Batch }\end{array}$ & & \begin{tabular}{|c|} 
товщ. 4,00 \\
Голандія
\end{tabular} & 0,59 & 0,59 & 0,59 & 0,60 & 0,60 & 0,594 & 0,396 & $\begin{array}{c}\text { PMБ - } \\
30 \mathrm{M}\end{array}$ \\
\hline 9. & $\begin{array}{c}6602 \\
\text { (Німеч- }\end{array}$ & & $\begin{array}{c}\text { товщ. 1,50 } \\
\text { Луцький }\end{array}$ & 0,54 & 0,55 & 0,54 & 0,53 & 0,56 & 0,544 & 0,362 & $\begin{array}{c}\text { за шка- } \\
\text { лою A, }\end{array}$ \\
\hline 10. & чина) & & $\begin{array}{c}\text { товщ. 1,75 } \\
\text { Луцький } \\
\end{array}$ & 0,54 & 0,54 & 0,56 & 0,55 & 0,54 & 0,546 & 0,364 & $\begin{array}{l}\text { поділки } \\
\text { шкали }\end{array}$ \\
\hline 11. & & & $\begin{array}{c}\text { Товщ. 2,00 } \\
\text { Луцький }\end{array}$ & 0,55 & 0,52 & 0,55 & 0,54 & 0,53 & 0,538 & 0,359 & 0,02 кГс \\
\hline 12. & & & \begin{tabular}{|l} 
товщ. 1,50 \\
Алек- \\
сінський
\end{tabular} & 0,57 & 0,56 & 0,56 & 0,55 & 0,56 & 0,560 & 0,373 & \\
\hline 13. & & Баладек & $\begin{array}{c}\text { товщ. 1,75 } \\
\text { Алек- } \\
\text { сінський }\end{array}$ & 0,56 & 0,56 & 0,54 & 0,58 & 0,57 & 0,562 & 0,375 & \\
\hline 14. & & & $\begin{array}{c}\text { товщ. 2,25 } \\
\text { Алек- } \\
\text { сінський }\end{array}$ & 0,55 & 0,58 & 0,57 & 0,56 & 0,56 & 0,564 & 0,376 & \\
\hline 15. & & & \begin{tabular}{|c|} 
товщ. 2,00 \\
Голандія
\end{tabular} & 0,58 & 0,58 & 0,57 & 0,59 & 0,58 & 0,580 & 0,387 & \\
\hline 16. & & & \begin{tabular}{|c|} 
товщ. 4,00 \\
Голандія
\end{tabular} & 0,57 & 0,57 & 0,59 & 0,59 & 0,58 & 0,580 & 0,387 & \\
\hline 17. & & $\begin{array}{l}\text { Хром- } \\
\text { ерзац }\end{array}$ & $\begin{array}{c}\text { мaca } \\
210 \text { г/ } \mathrm{m}^{2}\end{array}$ & 0,55 & 0,54 & 0,53 & 0,55 & 0,52 & 0,538 & 0,359 & \\
\hline
\end{tabular}


Продовження табл.

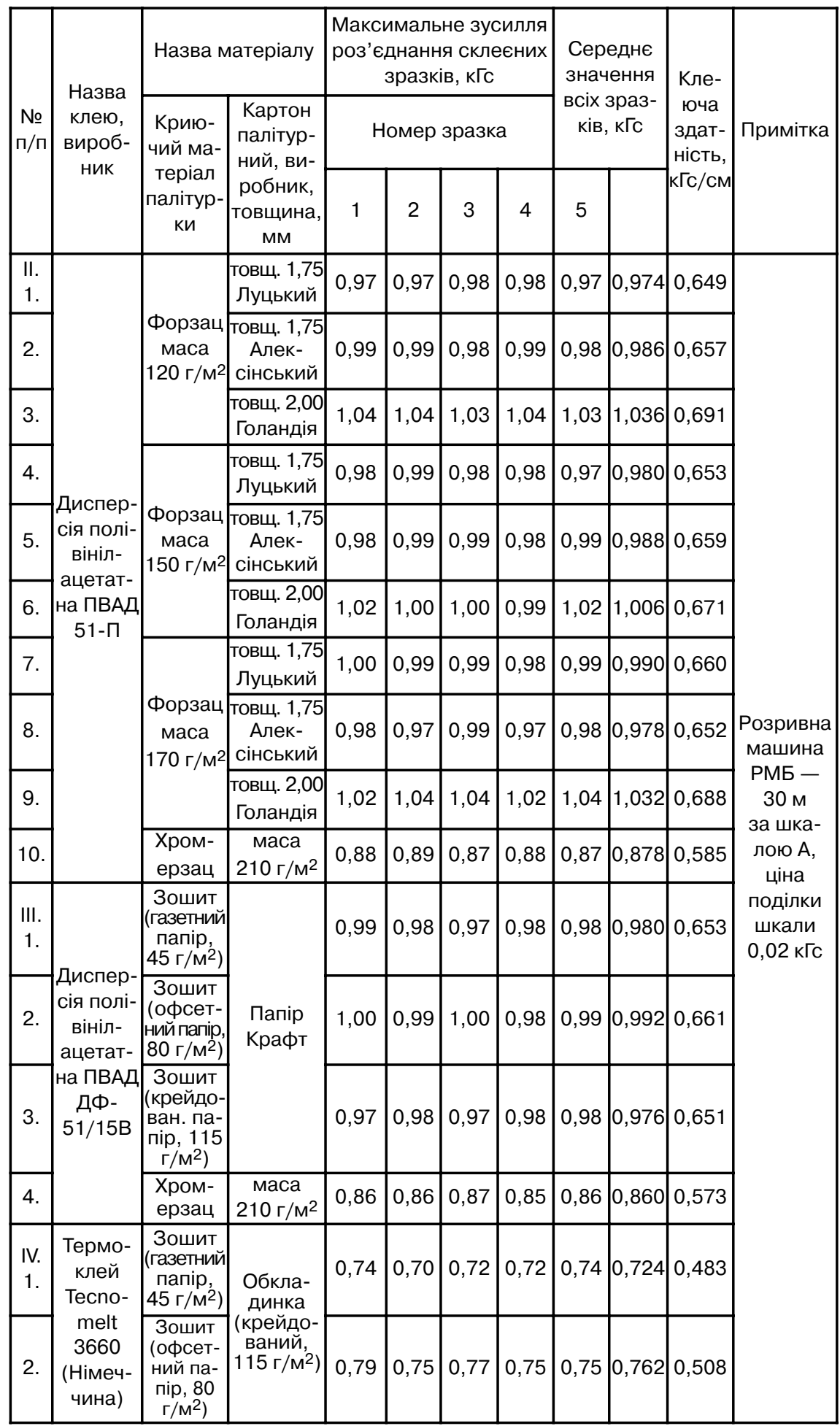


За підсумками отриманих результатів випробувань побудовано діаграми, що відтворюють показники максимальних зусиль роз'єднання склеєних зразків палітурних матеріалів (рис. 1-9).

\section{Висновки}

Аналіз експериментальної частини досліджень виявив необхідні для практичного використання при виготовленні книжкових оправ залежності, які виникають під час використання окремих видів клеїв із різними технологічними властивостями та різних палітурних матеріалів, що комплексно забезпечують виготовлення спрощених обкладинок за попередньо заданими основними характеристиками, дотримання яких забезпечить високоякісний та конкурентоздатний вид книжкової оправи.

Результати проведених досліджень створюють підстави (залежно від форматів і обсягів книг) при виготовленні спрощених

Закінчення табл.

\begin{tabular}{|c|c|c|c|c|c|c|c|c|c|c|c|}
\hline \multirow{3}{*}{$\begin{array}{l}\text { № } \\
\Pi / \Pi\end{array}$} & \multirow{3}{*}{$\begin{array}{l}\text { Назва } \\
\text { клею, } \\
\text { вироб- } \\
\text { ник }\end{array}$} & \multicolumn{2}{|c|}{ Назва матеріалу } & \multicolumn{4}{|c|}{$\begin{array}{c}\text { Максимальне зусилля } \\
\text { роз'єднання склеєних } \\
\text { зразків, кГс }\end{array}$} & \multirow{2}{*}{\multicolumn{2}{|c|}{$\begin{array}{c}\text { Середнє } \\
\text { значення } \\
\text { всіх зраз- } \\
\text { ків, кГС }\end{array}$}} & \multirow{3}{*}{\begin{tabular}{|l} 
Кле- \\
юча \\
здат- \\
ність, \\
КГс $/$ см
\end{tabular}} & \multirow{3}{*}{ Примітка } \\
\hline & & \multirow{2}{*}{\begin{tabular}{|c|} 
Крию- \\
чий ма- \\
теріал \\
палітур- \\
ки
\end{tabular}} & \multirow{2}{*}{\begin{tabular}{|c|} 
Картон \\
палітур- \\
ний, ви- \\
робник, \\
товщина, \\
мм
\end{tabular}} & \multicolumn{4}{|c|}{ Номер зразка } & & & & \\
\hline & & & & 1 & 2 & 3 & 4 & 5 & & & \\
\hline 3 & & \begin{tabular}{|c|} 
Зошит \\
(крей- \\
дован. \\
папір, \\
115 г/м²)
\end{tabular} & & 0,76 & 0,73 & 0,73 & 0,74 & 0,74 & 0,740 & 0,493 & \\
\hline 4 & & \begin{tabular}{l|} 
Хром- \\
ерзац
\end{tabular} & $\begin{array}{c}\text { мaca } \\
210 \mathrm{r} / \mathrm{M}^{2}\end{array}$ & 0,69 & 0,69 & 0,68 & 0,69 & 0,69 & 0,688 & 0,359 & Розр \\
\hline$V$ & & \begin{tabular}{|c|} 
Зошит \\
(газетний \\
папір, \\
$\left.45 г / \mathrm{M}^{2}\right)$ \\
\end{tabular} & & 0,72 & 0,73 & 0,73 & 0,72 & 0,74 & 0,728 & 0,485 & $\begin{array}{c}\text { машина } \\
\text { РМБ - } \\
30 \text { м }\end{array}$ \\
\hline 2 & $\begin{array}{c}\text { Термо- } \\
\text { клей } \\
\text { Swift } \\
\text { therm }\end{array}$ & \begin{tabular}{|c|} 
Зошит \\
(офсет- \\
ний па- \\
пір, \\
80 г/м²) \\
\end{tabular} & $\begin{array}{c}\text { Обкла- } \\
\text { динка } \\
\text { (крейдо- } \\
\text { ваний, }\end{array}$ & 0,75 & 0,74 & 0,75 & 0,74 & 0,73 & 0,742 & 0,495 & $\begin{array}{c}\text { лаю А, } \\
\text { ціна } \\
\text { поділки } \\
\text { шкали }\end{array}$ \\
\hline 3 & $\begin{array}{l}8026 \\
\text { (Фін- } \\
\text { ляндія) }\end{array}$ & \begin{tabular}{|c|} 
Зошит \\
(крей- \\
дован. \\
папір, \\
115 г/м²)
\end{tabular} & $\left.115 \mathrm{r} / \mathrm{M}^{2}\right)$ & 0,73 & 0,72 & 0,73 & 0,72 & 0,73 & 0,726 & $0,484 \mid$ & $0,02 \mathrm{k}\lceil\mathrm{c}$ \\
\hline & & $\begin{array}{l}\text { Хром- } \\
\text { ерзац }\end{array}$ & $\begin{array}{c}\text { мaca } \\
210 г / \mathrm{M}^{2}\end{array}$ & 0,66 & 0,67 & 0,66 & 0,66 & 0,67 & 0,664 & 0,443 & \\
\hline
\end{tabular}

1Луцький - ТзОВ «Луцька картонно-паперова фабрика-Україна»; ${ }^{2}$ Алексинский - АО «Алексинская бумажно картонная фабрика»; ЗГоландія - Eskabord, «Eska Graphic Board B.V.» (Голандія) 


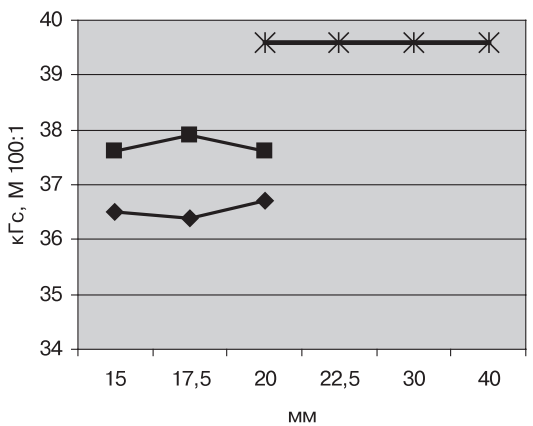

Рис. 1. Максимальне зусилля роз'єднання склеєних зразків при застосуванні клею PLAKAL Batch 6602 (Німеччина, табл., поз. 1...8)

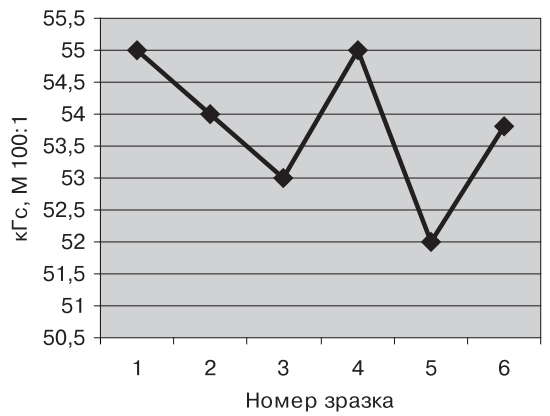

Рис. 3. Максимальне зусилля роз'єднання склеєних зразків при застосуванні клею PLAKAL Batch 6602 (Німеччина, табл., поз. 17)

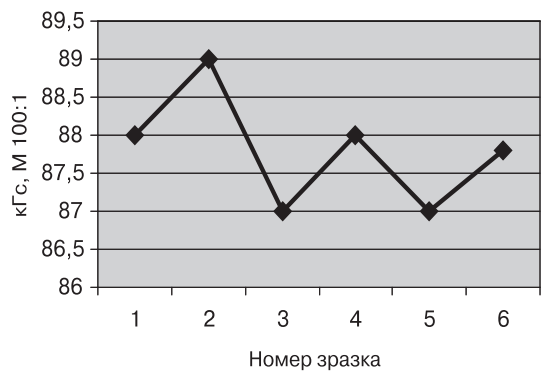

Рис. 5. Максимальне зусилля роз'єднання склеєних зразків при застосуванні клею дисперсія полівінілацетатна ПВАД 51-П (табл., розд. II, поз. 10)

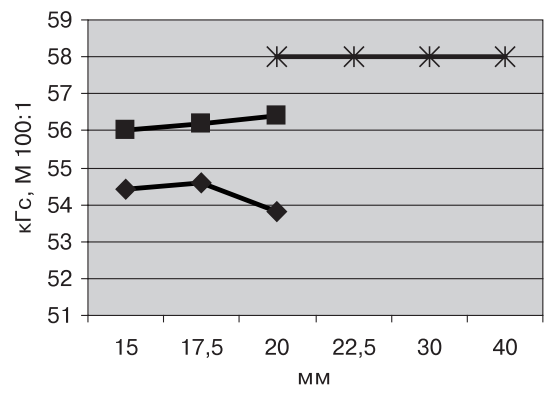

Рис. 2. Максимальне зусилля роз'єднання склеєних зразків при застосуванні клею PLAKAL Batch 6602 (Німеччина, табл., поз. 9...16)

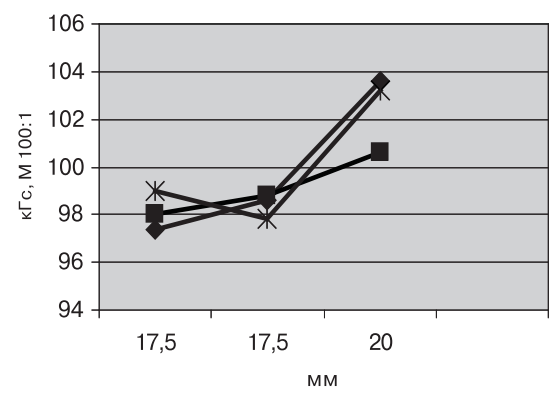

Рис. 4. Максимальне зусилля роз'єднання склеєних зразків при застосуванні клею дисперсія полівінілацетатна ПВАД 51-П

(табл., розд. II, поз. 1...9)

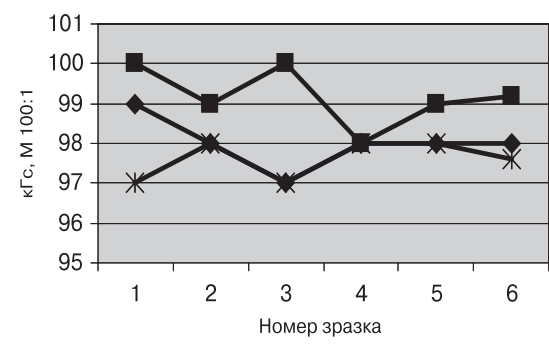

Рис. 6. Максимальне зусилля роз'єднання склеєних зразків при застосуванні клею дисперсія полівінілацетатна ПВАД ДФ-51/15В (табл., розд. III, поз. 1...3) 
книжкових оправ, здійснювати вибір окремих палітурних матеріалів і клеїв з урахуванням їхньої пріоритетності в застосуванні та поєднанні та, які $з$ не- обхідною виробничою вірогідністю забезпечать дотримання умов, що наблизять показники спрощених палітурок до основних переваг твердої палітурки.

\section{Список використаної літератури}

1. Malcolm G. K. Designer's postpress companion // NAPL, National Association for Printing Leadership, Paramus. New Jersey, 2005.

2. Пат. № 25601А України, МПК 6B 42D 3/00. Конструкція книжковожурнальної обкладинки і спосіб її виготовлення / Мартинюк М. С., Гавенко С. Ф., Кулік Л. Й. Заявл. 14.04.98; Опубл. 25.12.98. Бюл. № 6.

3. Пат. № 29271А України, В 42С 15/00. Спосіб приєднання суперобкладинки до обкладинки / Мартинюк М. С., Гавенко С. Ф., Кулік Л. Й. Заявл. 14.04.1998; Опубл. 16.10.2000. Бюл. № 5.

4. Лазаренко Е. Т. Поліграфічні матеріали / Жидецький Ю. Ц., Лазаренко Е. Т., Лотошинська Н. Д. Львів: Афіша, 2000.

5. СОУ 22.2-02477019-15:2010. Поліграфія. Обкладинки та палітурки. Київ: Держкомтелерадіо України, 2010.

6. J. Peacock. Book production. London: BLUPRINT, The publishers association, 1998.

7. Casper, Scott E., et al. Textbooks today and tomorrow: a conversation about history, pedagogy and economics // Journal of American History. 2014. 100(4). pp. 1139-1169.

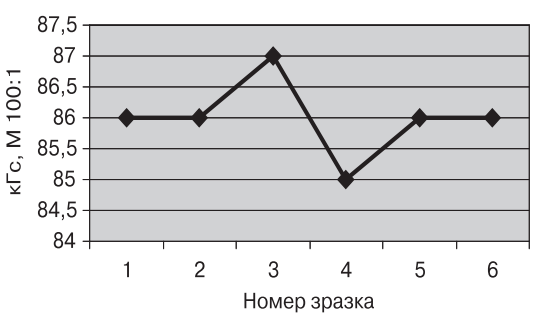

Рис. 7. Максимальне зусилля роз'єднання склеєних зразків при застосуванні клею дисперсія полівінілацетатна ПВАД ДФ-51/15В (табл., розд. III, поз. 4)

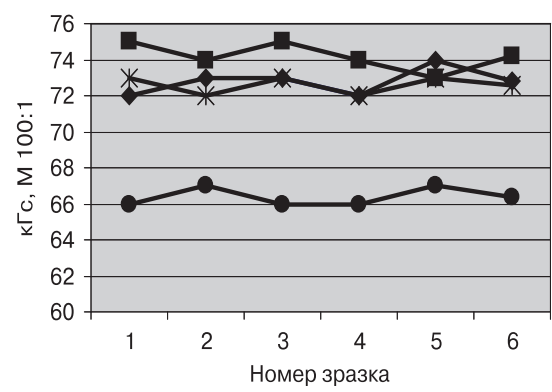

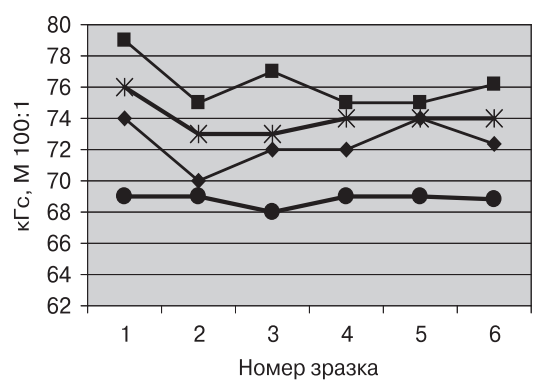

Рис. 8. Максимальне зусилля роз'єднання склеєних зразків при застосуванні термоклею Термоклей Tecnomelt 3660 (Німеччина, табл., розд. IV, поз. 1...4)

Рис. 9. Максимальне зусилля роз'єднання склеєних зразків при застосуванні термоклею Термоклей Swift therm 8026 (Фінляндія, табл., розд. V, поз. 1...4) 
8. Пат. 32803 А України, B42D 3/00 Конструкція книжково-журнальної обкладинки і спосіб їі виготовлення / Мартинюк М. С., Гавенко С. Ф., Кулік Л. Й. Заявл. 28.04.98; Опубл. 15.02.2001. Бюл. № 1.

9. СОУ 22.2-02477019-09:2007. Видання. Видавниче оформлення і поліграфічне виконання. Номенклатура показників якості. Київ: Держкомтелерадіо України, 2007.

10. Мартинюк М. С. Удосконалення конструкцій книжкових оправ та оптимізація технології їх виготовлення: Автореф. дис...канд. техн. наук: 05.05.01. Львів: Українська академія друкарства, 2002.

\section{References}

1. Malcolm, G. K. (2005). Designer's postpress companion. New Jersey [in English].

2. Martyniuk, M. S., Havenko, S. F. \& Kulik, L. I. Konstruktsiia knyzhkovozhurnalnoi obkladynky i sposib yii vyhotovlennia [The construction of the bookmagazine cover and the way of its making] // Patent № UA25601A. Publish 25.12.98 [in Ukrainian].

3. Martyniuk, M. S., Havenko, S. F. \& Kulik, L. I. Sposib pryiednannia superobkladynky do obkladynky [Method of attaching jacket to the cover] // Patent № UA29271A. Publish 16.10.2000 [in Ukrainian].

4. Zhydetskyi, lu. Ts., Lazarenko, E. T. \& Lotoshynska, N. D. (2000). Polihrafichni materialy [Polygraphic materials]. Lviv: Afisha [in Ukrainian].

5. National standards of Ukraine. (2010). SOU 22.2-02477019-15:2010. Polihrafiia. Obkladynky ta paliturky [Printing industry. Covers and bindings]. Kyiv: Derzhkomteleradio Ukrainy [in Ukrainian].

6. Peacock, J. (1998). Book production. London: BLUPRINT, The publishers association [in English].

7. Casper, Scott, E. \& et al. (2014). Textbooks today and tomorrow: A conversation about history, pedagogy and economics. Journal of American History, 100(4), 1139-1169 [in English].

8. Martyniuk, M. S., Havenko, S. F. \& Kulik, L. I. Konstruktsiia knyzhkovozhurnalnoi obkladynky i sposib yii vyhotovlennia [The construction of the bookmagazine cover and the way of its making] // Patent № UA32803 A. Publish 15.02.2001 [in Ukrainian].

9. National standards of Ukraine. (2007). SOU 22.2-02477019-09:2007. Vydannia. Vydavnyche oformlennia i polihrafichne vykonannia. Nomenklatura pokaznykiv yakosti [Editions. Publishing and polygraphic execution. Nomenclature of quality scores]. Kyiv: Derzhkomteleradio Ukrainy [in Ukrainian].

10. Martyniuk, M. S. (2002). Udoskonalennia konstruktsii knyzhkovykh oprav ta optymizatsiia tekhnolohii yikh vyhotovlennia [Improving the design of book frames and optimizing the technology for their production]. Lviv: Ukrainska akademiia drukarstva [in Ukrainian].

\section{На примере проведенных исследований изготовления книжных переплётов выявлены необходимые для прак- тического использования зависимости, возникающие при использовании отдельных видов клеев с различными технологическими свойствами и различных переплетных}




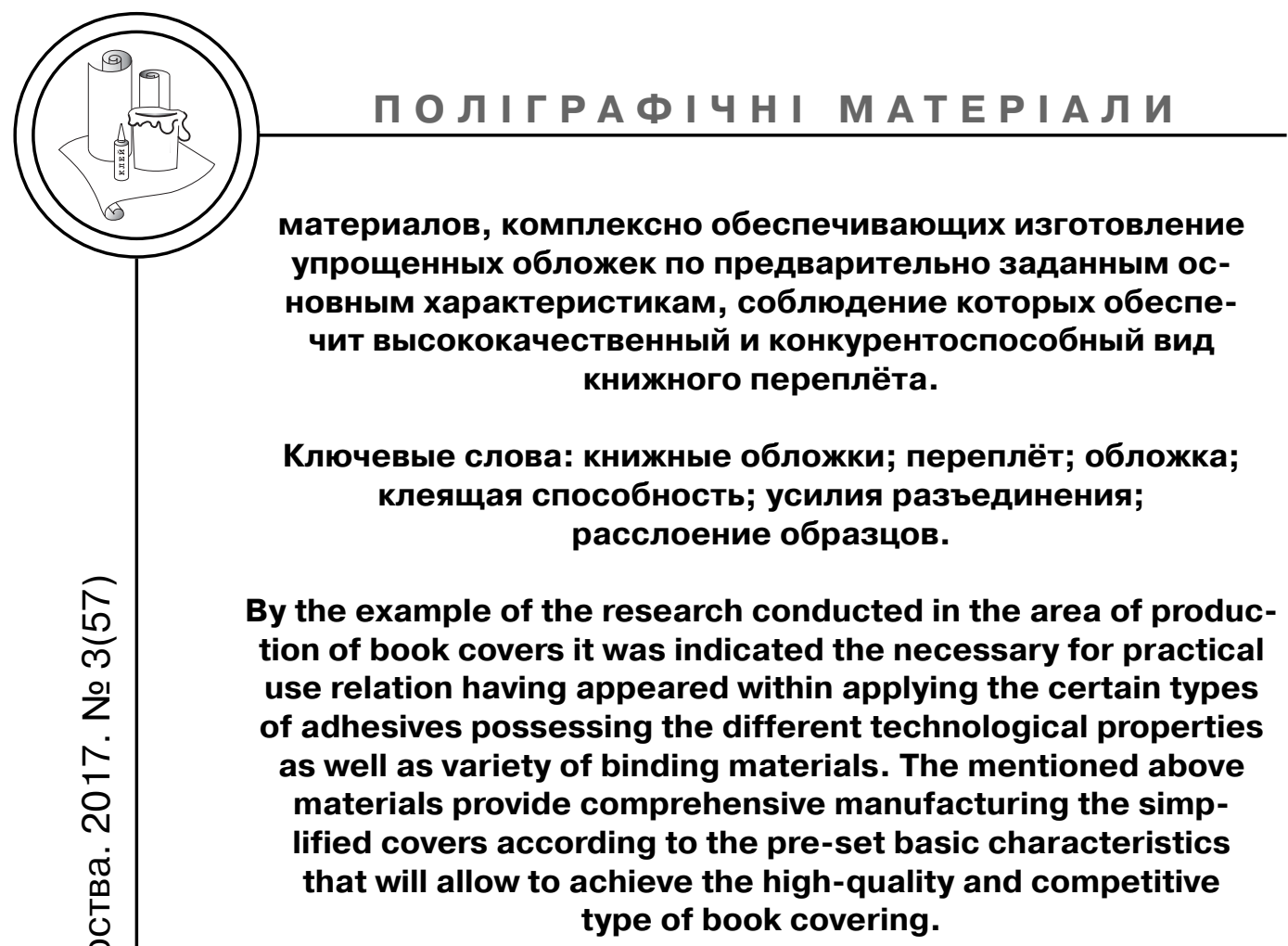

Keywords: book covers; binding cover; cover; adhesive capacity; force of separation; delamination of samples.

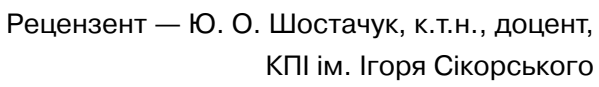

